\title{
Cervical Cancer cT4 TNM Finding v8
}

National Cancer Institute

\section{Source}

National Cancer Institute. Cervical Cancer cT4 TNM Finding v8. NCI Thesaurus. Code C139702.

Cervical cancer invading the mucosa of the bladder or rectum, and/or extending beyond the true pelvis (bullous edema is not sufficient to classify a tumor as T4). (from AJCC 8th Ed.) 